\title{
Sex Has a Meaning and Sex Differences Are Real
}

\author{
A review of David C. Geary, Evolution of Vulnerability: Implications for Sex Differences \\ in Health and Development, Academic Press: New York, 2015, 444 pp., \\ ISBN 978-0-12-801562-9 (paperback), \$50.96
}

\author{
Craig Bielert ${ }^{1}$
}

Published online: 9 March 2016

(C) Springer International Publishing 2016

In 1871, Charles R. Darwin published his book, The Descent of Man and Selection in Relation to Sex (Darwin 1899). He discussed his ideas on the origins of dimorphic features of anatomy, citing examples of insects, crustaceans, birds, and mammals. Although he did not include behavior in his exhaustive coverage, it was indirectly discussed, because he suggested that male weaponry existed because it had the potential to give specific males an advantage in intrasexual combat. Females were not involved in such agonistic battles and so would not benefit from the burdensome and unused antlers, horns, or tusks. Since these contests were being exhibited by one sex and not by the other, they could certainly qualify as "sexually dimorphic behaviors" even if never presented and discussed by Darwin as such. Mating behavior for species with internal fertilization would also obviously reflect a sexual dimorphism. However, its causal foundations could possibly be attributed to differing internal hormonal environments rather than differing central nervous system organization. Frank Beach (1974) focused upon prepubertal development of urination patterns in dogs as being an example of a sexually dimorphic behavior pattern that is exhibited in the absence of the activational action of gonadal hormones. Field observations on a wide variety of primates have confirmed a wide variety of sexually dimorphic behaviors (Bernstein 1978). Harry Harlow's work with surrogatereared rhesus monkeys (Macaca mulatta) established that these behavioral differences did not require exposure to adult models for their development and display and since these

Craig Bielert

Craig.Bielert@oneonta.edu

1 Department of Psychology, State University of New York at Oneonta, Oneonta, NY 13820, USA young rhesus monkeys were all prepubertal, there was confirmation of the independence of these behaviors from circulating hormones (Harlow 1971). Harlow's work provided the appropriate backdrop for the experimental work with rhesus carried out by Charles Phoenix, Arnold Gerall, Robert Goy, and William C. Young that confirmed the organizational action of gonadal hormone exposure in utero (Goy 1968). The extension of this to humans is more problematic because ethics prevent direct manipulation, and a necessary reliance on clinical conditions is in some respects less than ideal, although congenital adrenal hyperplasia has been a disorder which has allowed for appropriate examination.

For a great many people, the validity of sex differences is well-established and beyond question at the level of behavior and the central nervous system. However, the field is experiencing an inappropriate shift where the term "gender" is being substituted for the word "sex" even in situations where it is clearly inappropriate. For example, a 2015 work by Haynh et al. (2015) was published as a paper entitled "Forensic Identification of Gender from Fingerprints." The very first table in the paper is headed "Average amino acid concentration (mM) values for males and females derived from sweat" and the very first figure has reference to "males" and "females." Although the terms "man" and "woman" never appear in the article, these terms might have been appropriate under the article's title. The first thing I want to commend Geary for is his sensitivity to the appropriate use of terminology; the term "gender" does not even appear in the book's index. I doubt, however, that this was much of an effort for a man who has published an approximately 400-page book with the title Male, Female: the Evolution of Human Sex Differences (Geary 2005).

In this reviewed book, the conceptual model which Geary sets up to examine is a simple and straightforward one: "traits that have been elaborated through sexual or social selection 
are especially vulnerable to disruption by exposure to environmental and social stressors" (p. 2). He carries out a masterful consideration of this. He reviews condition-dependent traits in both human and nonhuman species. Just as Darwin, he pulls examples from insects, birds, and mammals, but Geary throws in fish as well. Geary reports that by including the nonhuman data, he gained a better understanding of condition-dependent traits. He also comments that differential effects across the species are accurately understood through an evolutionary perspective. To this reviewer, it seems as if there is an underlying acceptance by Geary of the view that certain traits are effective, or, I am assuming here, "honest signals," because they convey information about the individual's level of exposure to stressors and their ability to cope with them. This all seems very reasonable at a general level, and yet when specific cases are examined, the acceptance of honesty can be questioned. One example here might be the perineal elaboration shown by certain female primates and the reported phenomenon of "pseudo-estrus" first described by Blaffer-Hrdy for female langurs (Hrdy 1977) but also discussed for female hamadryas baboons by Zinner and Drescher (2000) and Swedell (2006). Geary points out that identifying traits that have been selected to be vulnerable is difficult, because differences across species are going to be encountered. He also points out that the existing literature does not allow for a careful assessment of all of his predictions.

In the case of humans, Geary places his emphasis on a variety of vulnerabilities such as physical, behavioral and cognitive. He examines a number of interesting relationships and his ultimate goal is to encourage a better understanding and assessment of how people respond to stressors and how their impact is related to sex, age, and trait.

The approximately 300 -page text is added to by a 67 -page bibliography. Five of the eight chapters carry tables; these total 22 , and the average number of pages for each one is about five and a half pages. The book is presented with a total of nine full-color figures and 33 full-color photos. Elsevier should be praised for the acceptance and presentation of a work which is this extensively researched and documented. The field of evolutionary biology can only benefit from the publication of books such as this or The Runes of Evolution by Simon Conway-Morris (2015), another recently published book of about 300 text pages accompanied by 156 pages of chapter notes.

This volume should stand as a reference source for a number of years, since the citations included a number from the year 2014, and since the final publication date of 2015 is almost as current as it is possible to achieve.

The area of sex differences is one that is being explored at a number of levels, and as a consequence this volume, with its very broad coverage, becomes very topical. Geary's book is relevant to a consideration of recently published articles such as "The Human Sex Ratio from Conception to Birth" (Orzack et al. 2015), "Elevated Fetal Steroidogenic Activity in Autism" (Baron-Cohen et al. 2015), and "The Sexual Identity of Adult Intestinal Cell Controls Organ Size and Plasticity" (Hudry et al. 2016). Geary in his final chapter states "a broadly evolutionarily informed understanding of sex differences has the potential to contribute to not only this research but also research and interventions in the many other facets of life that influence well-being.... This broader perspective will help to develop better methods to assess and address the different ways in which women and men and girls and boys react to the stresses of life, and a better understanding of exactly what constitutes a stressor and why" (p. 283).

In a bylined interview with Carole Jahme 2015 in the Manchester Guardian, Geary was asked to review the WHO's European Campaign, Health 2020, and see what his hypothesis could add. He responded:

There's good things, but they're saying sex differences are not important and what's important is socialization and culturation, which means they're going to miss sexspecific sensitivities to stressors and by not considering these they may underestimate the negative effects. By taking sex differences seriously the WHO could design studies that will provide a more thorough and complete understanding of the factors that undermine well-being and the ability to achieve one's full potential (p. 2).

Geary makes it clear that although vulnerability from a life history perspective would focus upon how stresses affect the timing of events such as menarche, a consideration of such issues is beyond the scope of his intended coverage.

I enjoyed reading Geary's book. I cannot assure you that you will come away from it giving his ideas your full support, but it is my opinion that if you find anything in this review resonating positively with your own attitudes on sex differences, you will find this to be a thought-provoking volume which is well worth the reading time and price. I hope that Geary will continue to research in this area and that it won't take nearly two decades, the period which he reports it took for this book to come to fruition, before he again presents a fleshed-out volume on a topic of importance in the area of evolutionary studies.

Acknowledgments The author gratefully acknowledges suggestions provided by Dr. Andrew Gallup. The kind support provided by Dr. Constance Anderson is also recognized, as is the expert typing and editorial work provided by Ms. Jill Grundfest. Any deletions or errors are the author's responsibility.

\section{Compliance with Ethical Standards}

Conflict of Interest The author declares that there is no conflict of interest. 


\section{References}

Baron-Cohen, S., Auyeng, B., Norgaard-Pederen, B., Hougaard, D. M., Abdallah, M. W., Melgaard, L., Cohen, A. S., Chakrabarti, B., Ruta, L., \& Lombardo, M. V. (2015). Elevated fetal steroidogenic activity in autism. Molecular Psychiatry, 20, 369-376.

Beach, F. A. (1974). Effects of gonadal hormones on urinary behavior in dogs. Physiology and Behavior, 12, 1005-1013.

Bernstein, I. S. (1978). Sex differences in the behavior of nonhuman primates. Social Science and Medicine Part B: Medical Anthropology, 12, 151-154.

Conway-Morris, S. (2015). The runes of evolution: how the universe became self-aware. West Conshohoken PA: Templeton Press.

Darwin, C. (1899). The descent of man and selection in relation to sex. New York: D. Appleton and Company.

Geary, D. C. (2005). Male, female: the evolution of human sex differences. Washington: American Psychological Assn.

Goy, R. W. (1968). Organizing effects of androgen on the behaviour of rhesus monkeys. In R. P. Michael (Ed.), Endocrinology and human behaviour (pp. 12-31). London: Oxford University Press.

Harlow, H. F. (1971). Learning to love. San Francisco: Albion Publishing Co.
Haynh, C., Brunelle, E., Halamkova, H., Agudelo, J., \& Halamek, J. (2015). Analytic Chemistry, 87, 11531-11536. doi:10.1021/acs. analchem.5603323.

Hrdy, S. B. (1977). The langurs of Abu: female and male strategies of reproduction. Cambridge: Harvard University Press.

Hudry, B., Khadayates, S., \& Miguel-Aliaga, I. (2016). The sexual identity of adult intestinal stem cells controls organ size and plasticity. Nature, 530, 344-348. doi:10.1038/nature1695.

Jahme, C. (2015). Sex differences and vulnerability: how the male-female divide affects health. The Manchester Guardian (10 April 2015). http:www.theguardian.com/science/blog/2015/apr/10/sexdifferences-and-vulnerability-how-the-male-female-divide-affectshealth

Orzack, S. H., Stubblefield, J. W., Akmaev, V. R., Colls, P., Munne, S., Scholl, T., Steinsaltz, D., Zuckerman, J. E. (2015). The human sex ratio from conception to birth, Proceedings of the National Academy of Science Early Edition. www.pnas.org/cg/doi/10.1073/pnas. 1416546112

Swedell, L. (2006). Strategies of sex and survival in hamadryas baboons: through a female lens. Upper Saddle River: Prentice Hall.

Zinner, D., \& Drescher, T. (2000). Sexual swellings in female hamadryas baboons after male take-overs: "Deceptive" swellings as possible female counterstrategy against infanticide. American Journal of Primatology, 52, 157-168. 